Tohoku J. Exp. Med., 2004, 204, 11-16

\title{
Effects of Granulocyte-Colony Stimulating Factor on Wound Healing in a Mouse Model of Burn Trauma
}

\author{
Erol Eroglu, Fatih Agalar, Irfan Altuntas ${ }^{1}$ and Fusun Eroglu ${ }^{2}$ \\ Department of General Surgery, ${ }^{1}$ Department of Biochemistry, and ${ }^{2}$ Department \\ Anaesthesiology, Suleyman Demirel University, School of Medicine, Isparta, \\ Turkey
}

Eroglu, E., Agalar, F., Altuntas, I. and Eroglu, F. Effects of GlanulocyteColony Simulating Factor on Wound Healing in a Mouse Model of Burn Trauma. Tohoku J. Exp. Med., 2004, 204 (1), 11-16 — The effects of burn trauma and granulocyte-colony stimulating factor (G-CSF) treatment on wound healing in a surgical incision model were studied. Sixty adult male mice were used in this study. Under general anesthesia hot water at $97^{\circ} \mathrm{C}$ was applied for $3 \mathrm{sec}$ to the dorsum of the mice in order to achieve $20 \%$ burn wound. After burn trauma, full thickness midline skin incision $2 \mathrm{~cm}$ in length was performed on the abdominal wall and then were sutured primarily with 4/0 polypropylene. In Group I only skin incision was performed, group II had skin incision and burn, in group III G-CSF (0.03 BU/30 g) was applied intraperitoneally after burn and skin incision. Breaking strength and 5-hydroxyproline (5-HP) levels of the wounds were calculated 5 and 10 days after the procedure. 5-HP levels and breaking strength values showed statistical difference between groups II-III and I-II $(p<0.05)$. 5-HP levels were lowest in incision and burn group $(41.80 \mu \mathrm{g} / \mathrm{mg})$. Breaking strength levels were also lowest in the same group $(0.12$ $\mathrm{kg})(p<0.05)$. These results suggest that third degree burn causes a significant impairment on incisional wound healing and G-CSF ameliorates this impairment. burn; wound; wound healing; G-CSF

(C) 2004 Tohoku University Medical Press

Wound healing is a crucial issue in the treatment of extensive burns. Split-thickness autogenous skin graft remains the most effective method for treating burn wounds (Fratianne et al. 1993). Optimal treatment of extensive donor sites and other wounds in patients with major injuries can be frustrating for both physicians and nursing staffs and can cause great discomfort for the patients (Hansbrough 1995). Debridement and early grafting of third degree burns have been a highly recommended procedure in burn treatment. Delayed healing of skin-graft donor sites may be costly and troublesome, especially in extensively burned patients (Smith et al. 1993). Donor site dressing and management should maximize the ability of the wound to heal without increasing the risk of local infection and systemic infection. In an attempt to improve the wound healing vari-

Received July 7, 2003; revision accepted for publication May 18, 2004.

Address for reprints: Erol Eroglu, M. Turkes M. 5130. S., Doktorlar-Mühendisler Sitesi No. 15, 32200 Isparta, Turkey.

e-mail: heroleroglu@hotmail.com 
ous agents have been used; recombinant human growth hormone, keratinocyte sheets and dressings containing polyurethane membranes (Brown et al. 1989; Leicht et al. 1989; Herndon et al. 1990; Fratianne et al. 1993).

Wound healing is not a single process; many cellular and immunologic mechanisms may take place. It is a complex process involving interaction of several growth factors, matrix proteins, their receptors and immunomodulatory agents (Bhartiya et al. 1992). The major immunologic changes taking place in burn injury are depression of several neutrophil functions such as chemotaxis, phagocytosis, and oxidative burst (Fratianne et al. 1993). These alterations are of interest in the mechanisms contributing to poor wound healing.

G-CSF is a cytokine, which has been used to reverse the neutropenia associated with cytotoxic chemotherapy, bone marrow and haemopoietic stem cell transplantation (Metcals 1990). G-CSF proved to be effective in wound healing, and acts directly on neutrophil-restricted progenitor cells in their proliferation (Jyung et al. 1994; Cody et al. 1999). It also induces endothelial cell proliferation and migration (Bussolino et al. 1991). In an animal model of burns and infection, G-CSF treatment was found to increase chemotaxis (Mooney et al. 1988). It can be speculated that G-CSF augments the recruitment in vivo by effectively lowering the threshold for the chemotactic signals necessary to initiate directed neutrophils consistency to the wound site because it is known that G-CSF enhances the binding of polymorphonuclear leukocytes' (PMN) to chemotactic peptides in vitro (Cohen et al. 1988). Moore et al. (1990) found that patients with major trauma had inadequate granulocytopoieses and colonystimulating factors were deficient.

With the hypothesis that G-CSF may augment wound healing process in burn trauma, this paper aimed to evaluate whether burn trauma decreased wound healing and G-CSF had protective effect on this process.

\section{Materials and Methods}

Adult male mice from Animal laboratory Unit of SDU were used in this study. All of the guiding principles in the use and care of laboratory animals were strictly adhered to throughout the study. 60 mice were randomly allocated into 3 groups. Each group consisted of 20 animals. These were as follows; Groups I-control: skin incision in order to simulate donor site, Group II: skin incision and burn, Group III: skin incision, burn+G-CSF treatment. Under general anesthesia (Ketamin $10 \mathrm{mg} / \mathrm{kg}$ intraperitoneally+Xylazine $4 \mathrm{mg} / \mathrm{kg}$ intraperitoneally) the dorsum and the abdominal regions of the animals were shaved. To achieve about $20 \%$-third degree burn, hot boiling water at $97^{\circ} \mathrm{C}$ was applied for 3 seconds to the back part of the Group II and III animals. In all groups $2 \mathrm{~cm}$ full thickness skin incision on abdominal wall was made and primarily sutured with $4 / 0$ polypropylene.

In group III after skin incision and burn G-CSF (0.03 BU/30g) (Neupogen ${ }^{\circledR}$, Basel, Switzerland) was applied intraperitoneally for three days. Five days after the procedure ten animals in each group were terminally anesthetized with ether and a skin segment of $2.5 \times 2.5 \mathrm{~cm}$ in size, including the incision was excised from the abdominal wall. Breaking strength values were evaluated with a tensiometer (M250-2.5AXTestometric, Lancashire, England) in this tissue segment. 5-Hydroxyproline (5-HP) levels were measured in dry tissue of the excised samples with the method described previously (Woessner 1961). These procedures were repeated for the rest of animals on the 10th day.

Descriptive values were expressed as mean \pm s.D. In statistical analysis One-Way ANOVA (Post Hoc Test-Tukey's HSD) were used, and $p \leqq$ 0.05 value was accepted as significant.

\section{RESUlts}

Breaking strength values of groups were significantly different. Five days after the experiment the wounds of the ten animals in each group 
TABLE 1. Breaking Strength and Hydroxyproline values of the groups

\begin{tabular}{|c|c|c|c|c|}
\hline Groups & & $n$ & $\begin{array}{l}\text { Breaking Strength }(\mathrm{kg}) \\
(\text { mean } \pm \text { S.D. })\end{array}$ & $\begin{array}{c}\text { 5-Hydroxyproline }(\mu \mathrm{g} / \mathrm{mg}) \\
(\text { mean } \pm \text { S.D. })\end{array}$ \\
\hline \multicolumn{5}{|c|}{ I (incision) } \\
\hline & Day 5 & 10 & $0.14 \pm 0.03$ & $56.61 \pm 13.21$ \\
\hline & Day 10 & 10 & $0.23 \pm 0.03$ & $76.65 \pm 13.79$ \\
\hline \multicolumn{5}{|c|}{ II (incision + burn) } \\
\hline & Day 5 & 10 & $0.12 \pm 0.02$ & $54.43 \pm 10.65$ \\
\hline & Day 10 & 10 & $0.14 \pm 0.05$ & $41.80 \pm 12.35$ \\
\hline \multicolumn{5}{|c|}{ III (incision + burn + G-CSF) } \\
\hline & Day 5 & 10 & $0.13 \pm 0.02$ & $55.25 \pm 8.35$ \\
\hline & Day 10 & 10 & $0.27 \pm 0.05$ & $67.50 \pm 13.05$ \\
\hline
\end{tabular}

were removed. The lowest breaking strength levels were obtained in Group II $(0.12 \pm 0.02 \mathrm{~kg})$ and highest in Group I $(0.14 \pm 0.03 \mathrm{~kg})$ (Table 1). In the wounds removed on the 10th day, the lowest values of breaking strength were also seen in Group II $(0.14 \pm 0.05$ kg).

Statistical analyses revealed no significant difference between the breaking strength levels of 5th-day wounds, but there was a significant difference in 10th-day wounds $(p<0.05)$ (between
Groups II-III and I-II) (Fig. 1).

The changes in the values of 5-HP were in accordance with the changes of the values of breaking strength. In 5th-day wounds the lowest values were obtained in Group II $(54.43 \pm 10.65$ $\mu \mathrm{g} / \mathrm{mg}$ ) and in 10th-day wounds the lowest values were also in Group II $(41.80 \pm 12.35 \mu \mathrm{g} / \mathrm{mg}$ ) (Table $1)$. There were significant differences between Group II-III and I-II ( $p<0.05)$ (Fig. 2).

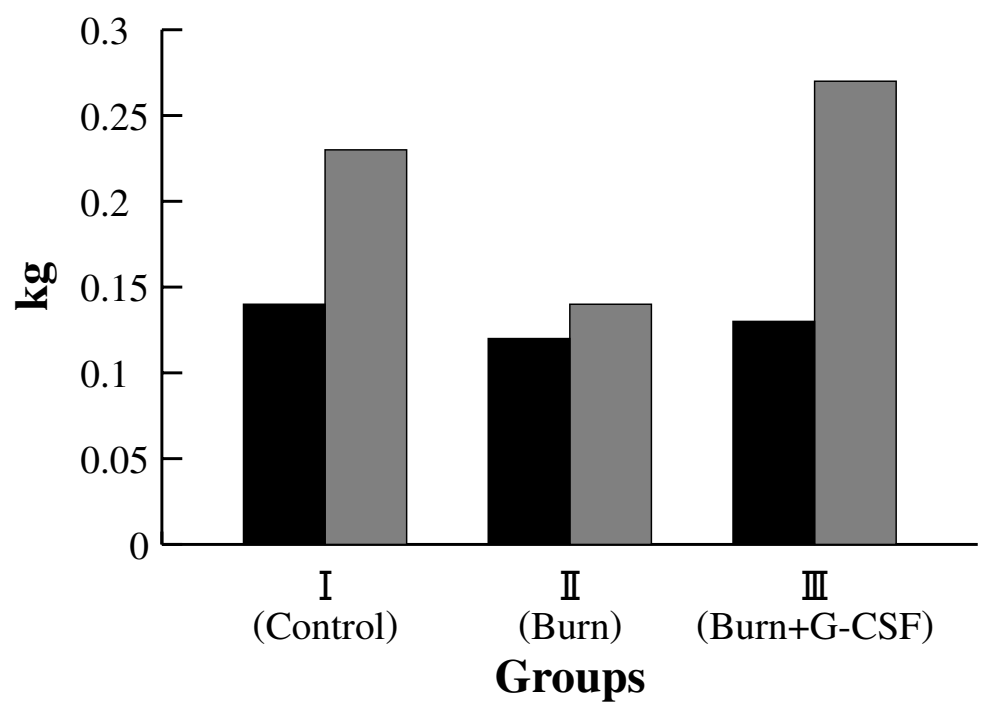

Fig. 1. Breaking strength levels of the groups at 5 th and 10th days (mean \pm s.D.). , 5th Day; $\quad$, 10th Day.

Statistically significance between group I and group II at 10th day, $p<0.05$.

** Statistically significance between group II and group III at 10th day, $p<0.05$. 


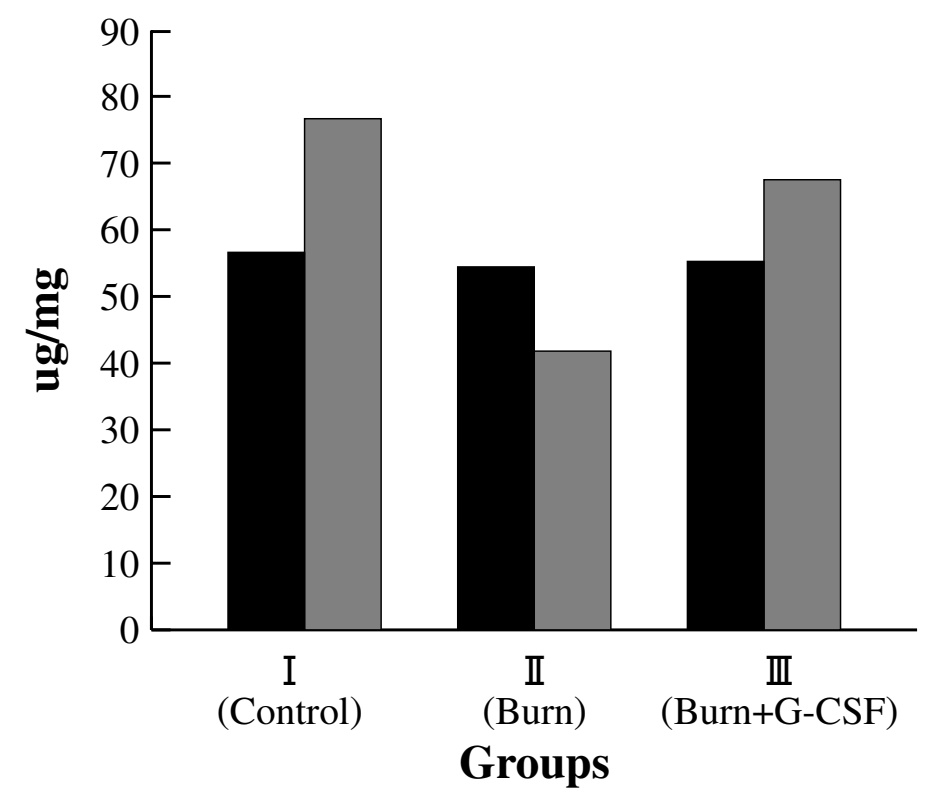

Fig. 2. 5-HP levels of the groups at 5th and 10th days (mean \pm S.D.).

口, 5th Day; , 10th Day.

* Statistically significance between group I and group II at 10th day, $p<0.05$.

${ }^{* *}$ Statistically significance between group II and group III at 10th day, $p<0.05$.

\section{Discussion}

The survival of extensively burned patients depends on many factors. Autografts remain the most effective method for treating burn wounds, and wound healing is also important in the management of these patients. In both 5thday and 10th-day wounds it was seen that incisional wound healing in burn group was impaired compared with the control group. Both breaking strength and hydroxyproline values in burn group(s) were lower than those of control group. This difference is more remarkable in 10th-day wounds.

It is well known that severe thermal injury impairs granulocyte production and its function, and induces a depression in the function of polymorphonuclear leukocytes (Sartorelli et al. 1991; Byorson and Somers 1993). It was also shown that thermal injuries are frequently associated with immunologic abnormalities including alterations of polymorphonuclear leukocyte-associated nonspecific resistance (Gruber and D'Alesandro
1989). We hypothesized that G-CSF could reverse these effects with its ability to enhance PMNL chemotaxis. In G-CSF treated group 10thday breaking strength and hydroxyproline levels were significantly higher than those observed in burn group. This may be due to an accelerating response of local wound healing in trauma, which has been augmented by G-CSF. G-CSF may accelerate several cascades of events such as chemotaxis, phagocytosis, and oxidative burst, which take place in wound healing. Levenson et al. (1965) have suggested a significant strong correlation between tensile strength of wound and its hydroxyproline content. Jyung et al. (1994) demonstrated positive effects of GM-CSF and G-CSF on wound healing. They claimed that increasing circulating white blood cells did not affect wound healing, stimulation of the granulocyte, macrophage, eosinophil colonies, and proliferation of the neutrophil-restricted progenitor cells are more important. G-CSF was also found to be effective in different surgical wounds (Besner et al. 1992; Van Lindert et al. 1995). Bussolino et al. (1991) 
showed that induced proliferation of endothelial cells by G-CSF and GM-CSF, and these immunomodulators had definite angiogenic activity on endothelium in rabbit cornea. Burn injury is known to decrease neutrophil chemotaxis (Nelson et al. 1987). In an animal model the decrease in the chemotaxis was corrected within 72 hours by G-CSF administration initiated at the time of the injury (Sartorelli et al. 1991). We may say that G-CSF and GM-CSF proved to have beneficial effects on wound healing process in animal studies. But we do not know what aspect of wound healing was involved in impairment of healing in the present study. Better understanding of the complex wound-healing cascade helps our approach to wound healing and its possible failure. From this viewpoint, it was seen that burn trauma impairs simulated wound healing in an experimental model, and G-CSF found to have beneficial effects on incisional wound healing.

\section{References}

Besner, G.E., Glick, P.L., Karp, M.P., Wang, W.C., Lobe, T.E., While, C.R. \& Cooney D.R. (1992) Recombinant human granulocyte colonystimulating factor promotes wound healing in a patient with congenital neutropenia. J. Pediatr. Surg., 27, 288-290.

Bhartiya, D. Sklarsh, J.W. \& Maheshwari, R.K. (1992) Enhanced wound healing in animal models by interferon and interferon inducer. J. Cell Phys., 150, 312-319.

Brown, G.L., Nancy, L.B., Griffen, J., Cramer, A.B., Yancey, J.M., Curtsinger, L.J., Holtzin, L., Schultz, G.S., Jurkiewicz, M.J. \& Lynch, J.B. (1989) Enhancement of wound healing by topical treatment with epidermal growth factor. $N$. Engl. J. Med., 321, 76-79.

Bussolino, F., Ziche, M., Wang, J.M., Alessi, D., Morbidelli, L., Cremona, O., Bosia, A., Marchisio, P.C. \& Mantovani, A. (1991) In vitro and in vivo activation of endothelial cells by colony-stimulating factors. J. Clin. Invest., 87, 986-995.

Byorson, A.B. \& Somers, S.D. (1993) Downregulation of chemotaxis of polymorphonuclear leukocytes following thermal injury involves two distinct mechanisms. J. Infect. Dis., 168, 120-127.
Cody, D.T., Funk, G.F., Wagner, D., Gidley, P.W., Graham, S.M. \& Hoffman, H.T. (1999) The use of granulocyte colony stimulating factor to promote wound healing in a neutropenic patient after head and neck surgery. Head Neck, 21, 172-175.

Cohen, A.M., Hines, D.K., Korach, E.S. \& Ratkin, B.J. (1988) In vivo activation of neutrophil function in hamsters by recombinant human granulocyte colony-stimulating factor. Infect. Immun., 56, 2861-2865.

Fratianne, R., Papay, F., Housini, I., Lang, C. \& Schafer, I.A. (1993) Keratinocyte allografts accelerate healing of split-thickness donor sites: applications for improved treatment of burns. $J$. Burn Care Rehabil., 14, 148-154.

Gruber, D.F. \& D'Alesandro, M.M. (1989) Alteration of rat polymorphonuclear leukocyte function after thermal injury. J. Burn Care Rehabil., 10, 394-401.

Hansbrough, J.F. (1995) Use of biobrane for extensive posterior donor site wounds. J. Burn Care Rehabil., 16, 335-336.

Herndon, D.N., Barrow, R.E., Kunkel, K.R., Broemeling, L. \& Rutan, R.L. (1990) Effects of recombinant human growth hormone on donor-site healing in severely burned children. Ann. Surg., 212, 424-429.

Jyung, R.W., Wu, L., Pierce, G.F. \& Mustoe, T.A. (1994) Granulocyte-macrophage colony-stimulating factor and granulocyte colony-stimulating factor: differential action on incisional wound healing. Surgery, 115, 325-334.

Leicht, P., Srim, E. \& Sorensen B. (1989) Treatment of donor sites. Duoderm or Omiderm? Burns Incl. Therm. Inj., 15, 7-10.

Levenson, S.M., Geever, E.F., Crowley, L.V., Oates, J.F., Bernard, C.W. \& Rosen, H. (1965) The healing of rat skin wounds. Ann. Surg., 161, 293-308.

Metcalf, D. (1990) The colony-stimulating factors: discovery, development and clinical applications. Cancer, 65, 2185-2195.

Mooney, D.P., Ganelli, R.L., O’Reilly, M. \& Hebert, J.C. (1988) Recombinant human granulocytecolony stimulating factor and pseudomonas burn wound sepsis. Arch. Surg., 123, 1353-1357.

Moore, F.A., Peterson, V.M. \& Moore, E.E. (1990) Inadequate granulopoiesis after major torso trauma. Arch. Surg., 108, 667-674.

Nelson, R., Hassien, S.R., Ahrenhold, D.H. \& Salem, 
L.D. (1987) Mechanisms of loss of human neutrophil chemotaxis following thermal injury. J. Burn Care Rehabil., 8, 496-502.

Sartorelli, K.H., Silver, G.M. \& Gamelli, R.L. (1991) The effect of granulocyte colony-stimulating factor (G-CSF) upon burn-induced defective neutrophil chemotaxis. J. Trauma, 31, 523-529.

Smith, D.J., Jr., Thomson, P.D., Bolton, L.L. \& Hutchinson, J.J. (1993) Microbiology and healing of the occluded skin graft donor site. Plast. Reconstr. Surg., 91, 1094-1097. van Lindert, A.C., Symons, E.A., Damen, B.F. \& Heintz, A.P. (1995) Wound healing after radical vulvectomy and inguino-femoral lymphadenectomy: experience with granulocyte colony stimulating factor (filgrastim, r-met Hu G-CSF). Eur. J. Obstet. Gynecol. Reprod. Biol., 62, 217-219.

Woessner, J.B. (1961) The determination of hydroxyproline in tissue and protein samples containing small proportions of this iminoacid. Arch. Biochem. Biophys., 93, 440-447. 